\title{
Geographic Information System Clinic of Health Services In Samarinda City Web-Based
}

\author{
Erna Mulyati \\ Software Engineering Technology, \\ Agricultural Polytechnic of \\ Samarinda, Samarinda, 75131, \\ Indonesia \\ ernotmulyati@gmail.com
}

\author{
Suci Ramadhani* \\ Software Engineering Technology, \\ Agricultural Polytechnic of \\ Samarinda, Samarinda, 75131, \\ Indonesia \\ suci.ramadhani.usu@gmail.com \\ *Corresponding author
}

\author{
Syafei Karim \\ Software Engineering Technology, \\ Agricultural Polytechnic of \\ Samarinda, Samarinda, 75131, \\ Indonesia \\ syfei_karim@politanisamarinda.ac.id
}

\begin{abstract}
Difficulties in finding clinics within a certain area often occur everywhere, so a number of clinics cannot meet the needs of the surrounding community. A health service clinic is a place of practice that is more than one general practitioner or specialist who works in health services. The purpose of this study is to create a web-based Geographic Information System (WebGis) regarding the distribution of clinics, especially in Samarinda City. The benefits of WebGis can present the location and information about the clinic. The search field can also search for information based on the expertise of doctors, in the form of general practitioners or specialists.
\end{abstract}

Keywords - Geographic Information System, Clinic, Web

\section{INTRODUCTION}

Samarinda is an area that is trying to further advance its region, with the potential that there have been all efforts made by the government, especially the Health Office to promote and advance the world of health. The condition of Samarinda City has increasingly made services to the community improved so that the information provided must be even more, one of which is information and location of community services, especially in the health clinic.

In the modern era like today, technology is very much helping human life in doing work and information needs. One of the information that society needs at this time is about geographic information, to get information about geography can be obtained through the internet media.

One of the presentation of geographic data information is by using GIS (Geographical Information System), GIS is a special information system that manages data that has spatial information (spatial references) or in a narrower sense, is a computer system that has the ability to build, store, managing and displaying geographically referenced information (Julianti et al., 2018).

From the research that has been researched previously, there are differences in the research to be carried out, namely the geographic information system displays a map of the location with the object of the health service clinic and there are several other features contained in the system.

\section{LITERATURE REVIEW}

According to research conducted by Eko Priyanto et al (2013), with his research entitled "Designing WebBased Geographical Information Systems (GIS) for Providing Information on Facilities and Personnel at the University of Lampung". The purpose of this research is to design a web-based Geographical Information System (GIS) to display facility information and data on lecturers and their work units at the University of Lampung. The benefit of this research is the web-based Geographic Information System (GIS) which is made to be a tool for visitors and the academic community to obtain information on the existence of lecturers' work units, building information, information on public facilities, and a map of the Lampung University area (Ramadhani, 2013).

According to research conducted by Zubair Shobrun Jamil et al (2015), with his research entitled "Designing a Web-Based Information System for Mapping Health Facilities in Padang City Using Google Maps Api". The purpose of this research is that the existence of a webbased Geographical Information System on health facilities can be an informative technology and an alternative for information search on health facilities in the city of Padang. The benefit of this application is that it can provide information to Padang city people about the location of health services.

According to research conducted by Nur Rochmah Dyah P.A et al (2015), with his research entitled "Geographical Information System for Web-Based Specialist Doctor Practices in the Province of D.I Yogyakarta". The purpose of this research is to produce a GIS as a specialist doctor's practice that provides information services to the public about health news. The benefits of this GIS are as a means of technology and science. This research uses Codeigniter and MySQL Framework software.

According to research conducted by Joko Siswanto et al (2016), with his research entitled "Designing Webgis Mapping Location of Social Institutions Using PMAPPER". The research objective was to build a webbased information system regarding the distribution map of the orphanage in Pekanbaru City. The benefit of this Webgis is that getting information about social 
institutions can be facilitated by a geographic information system that shows a map of the distribution of the social institutions. By using this geographic information system, the community will find it easier to access information to locate social institutions in Pekanbaru anytime and anywhere and can find their location more efficiently and effectively.

According to research conducted by M. Ramaddan Julianti et al (2018), with his research entitled "Designing a Web-Based Geographical Information System Mapping of Pharmacy Locations in the City of Bogor". The purpose of this study is to create a web-based geographic information system (WebGis) regarding the distribution of all pharmacies, especially in Bogor, using a web-based mapping approach. The benefit of this research is that WebGis can present integrated information from spatial data and non-spatial data. Information for the distribution of pharmacies has an interactive display that makes it easy for the public to find out the location of the pharmacy with a certain display.

\section{A. Geographic Information Systems}

Geographic Information System (GIS) is a computerbased system that was built with the aim of collecting, storing, processing and analyzing, and providing data and information from an object it provides on the surface of the earth. Basically GIS is several sub-systems that are interrelated in entering data, management data, discussed or data analysis and analysis results (Ekadanata et al., 2011).

Based on the above understanding it can be denied that GIS is a system that discusses information that references spatial for analysis of the earth's geographic surface.

\section{B. Health Clinic}

Clinic is a public health facility that was established to provide care to patients. Only clinics that only handle minor ailments like fever and so on, but also serve outpatients and inpatients. While more severe cases were submitted to the hospital (Aprianti \& Nurfajriyah, 2016).

Based on the above definition the clinic is a health institution used for treatment. Clinics can also be called specialized medical centers or health organizations that provide diagnosis or treatment of diseases and treatments, usually to one type of health problem or specialist. If the patient's illness is more severe then he will be referred to the hospital.

\section{Google Maps API}

Google Maps API is a library consisting of JavaScript. By using the Google Maps API, we can save time and money to build applications, allowing us to focus only on the data that will be needed (Swastikayana, 2011).

Some of the purposes of using the Google Maps API are to view locations, search for addresses, get driving directions and so on. Almost anything related to maps can take advantage of Google Maps. Google Maps (without API) was introduced in February 2005 and is a revolution in how maps are made on web pages, by allowing users to drag maps so they can navigate them (Mardhana dkk, 2016).

Based on the research above, it can be concluded that the Google Maps API is a library that can be used to build applications or mapping website pages and can be used to find locations and information about these locations for users.

\section{JavaScript}

JavaScript is a scripting language based on prototype-based programming concepts. This language is well known for its use on client-side websites and is also used to provide script access for objects that are embedded in other applications. JavaSript is used to access a program object along with other applications and is mainly used in client forms besides JavaScript as development for websites. JavaScript has dynamic, strong characteristics, becoming the language basis for prototyping with main class functions. JavaScript is designed like Java but still easy to handle (Swastikayana, 2011).

JavaScript is a client side web programming language. Because as a programming language, JavaScript can be used to create mathematical applications, simple animation effects, and even to create games. Most browsers currently support JavaScript. JavaScript documents can be created using an ordinary text editor, such as: Notepad, Wordpad, Notepad ++ , and others, by saving them in $*$.js format.

\section{RESEARCH METHOD}

This research was conducted at the Samarinda City Clinic as the place under study. The time of this research is approximately 10 (ten) months. Starting from October 2019 - August 2020, which consists of preparing proposals, collecting data, making applications and preparing thesis writing. The tools used in the Web-based Geographical Information System research in Samarinda City are as follows:

1. Hardware (Hardware)

a. Laptop Asus X442URR (Ram 12GB DDR4 Memory, Intel Core i5-8250U CPU $1.60 \mathrm{GHz}, 1 \mathrm{~TB}$ HDD)

b. Handphone Realme 3 Pro

c. Printer Epson L3110

2. Software (Software)
a. Xampp
b. MySQL database
c. Sublime Text
d. Google / Mozilla browser
e. Google Maps API

3. The materials used are as follows:

a. Health Service Clinic Location Data

A geographic information system that manages geographic or spatial information about health care clinics, as well as displaying detailed information 
available at the clinic. Modeling of the DFD level 0 process can be seen in Picture 1.

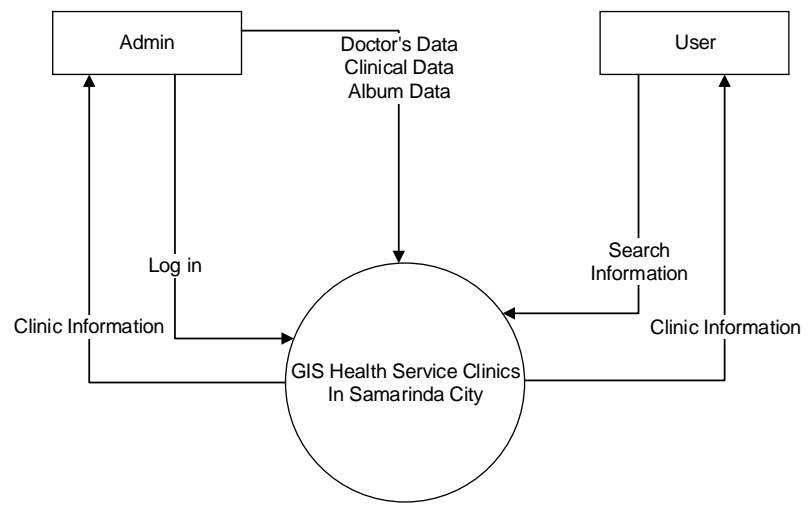

Picture 1. DFD Level 0

\section{RESUlTS AND DisCUSSION}

The result of the development of a web-based geographic information system for health service clinics in the city of Samarinda has six menus for admins, namely homepage, map, doctor data, map data, admin data and settings. Has three menus for users, namely the homepage, map and doctor's data. This Geographical Information System was created with the native PHP programming language version 7.2.9. The results of making a web-based geographic information system application for health service clinics in the city of Samarinda are:

1. Admin Menu Display

a. Login Page

The admin login page design can be seen in Picture 2.
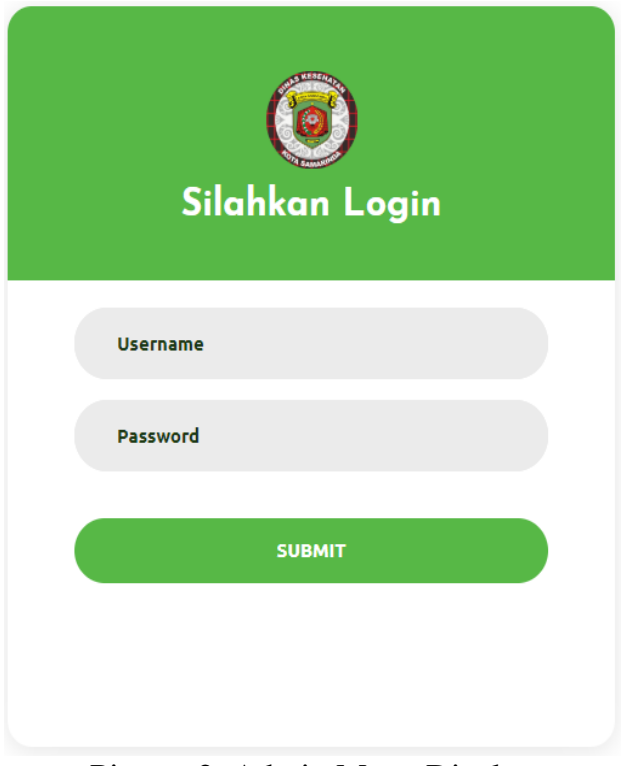

Picture 2. Admin Menu Display

Based on Picture 2, this admin login page is the admin stage of logging in to the application. On this page, there are username and password fields that the admin must fill in in order to proceed to another page and there is a submit button.

b. Home Page

The home page design can be seen in Picture 3 .

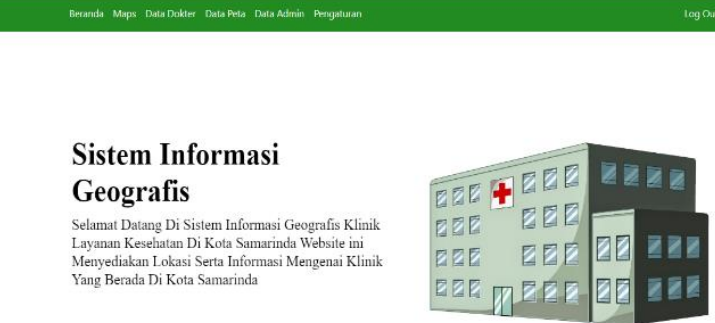

Picture 3. Admin Home Page

Based on Picture 3 is the web homepage display for admin, this page will display the web title, home menu, map menu to display maps, doctor data menu to display data to doctors, map data menu to display clinic data, data menu admin, settings menu, image and text area in the form of a brief explanation of this geographic information system web and there is a logout feature.

c. Map Page

The map page design can be seen in Picture 4 .

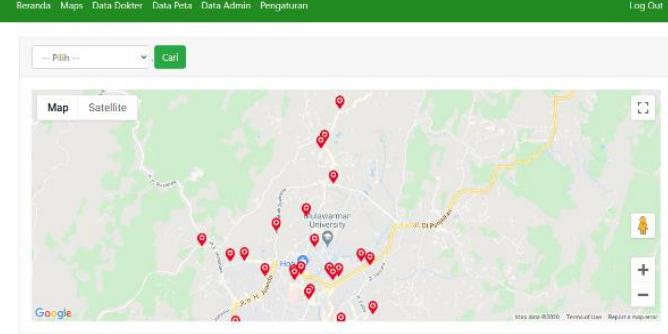

Picture 4. Admin Map Page

Based on Picture 4, it is the stage of displaying a map or location point of the clinic, and there are features of clinic search, homepage, maps, doctor data, map data, admin data, settings and logout.

\section{d. Map Detail Page}

The map detail page design can be seen in Picture 5 .

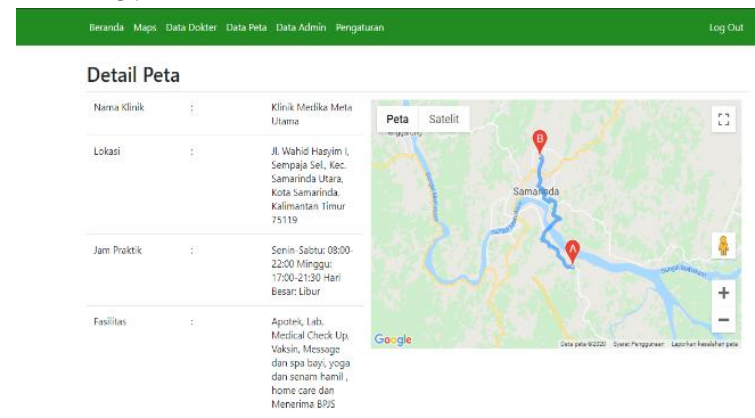

Picture 5. Admin Map Detail Page 
Based on Pictures 5, it is the stage of displaying a detailed map of the location points that have been selected from the map in the form of map information consisting of coordinate points and routes to the clinic, name of the clinic, location, practice hours, facilities, information, telephone number, list of doctors who work at the clinic and clinic photos, and there are several features to go to other pages.

e. Doctor Data Page

The doctor data page design can be seen in Picture 6.

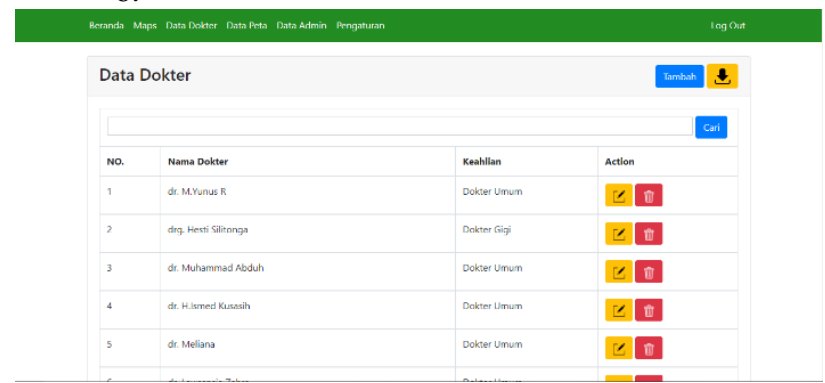

Picture 6. Admin Doctor Data Page

Based on Picture 6 is the stage of presenting doctor's data. On this page there are buttons add, edit, delete, search and download data buttons that can be used to make changes to doctor data, search for doctor data and can download existing doctor data, and there are several features to go to the page other.

\section{f. Map Data Page}

The map data page design can be seen in Picture 7 .

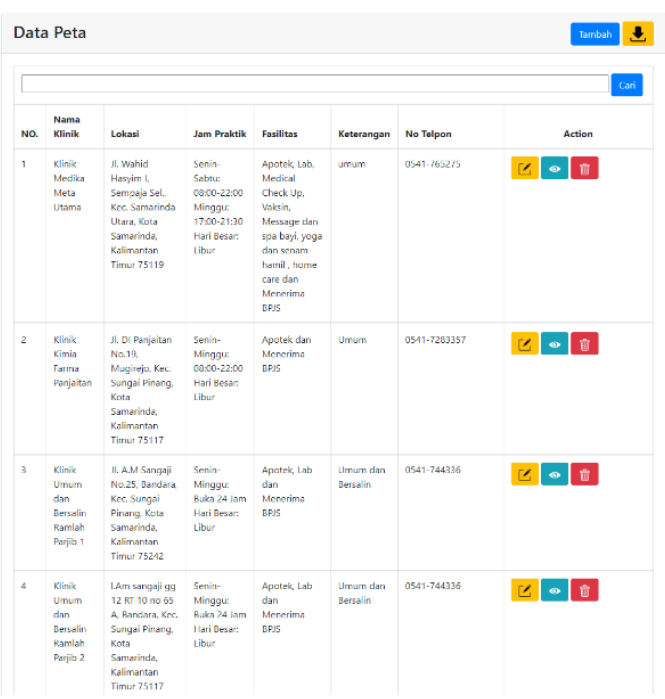

Picture 7. Map Data Page

Based on Picture 7, this is the stage of displaying map data. On this page there are buttons add, edit, see details to view detailed map data, delete, search and download data buttons that can be used to make changes to map data, search map data and can download existing map data. and there are several features to go to other pages.

\section{g. Admin Data Page}

The admin data page design can be seen in Picture 8.
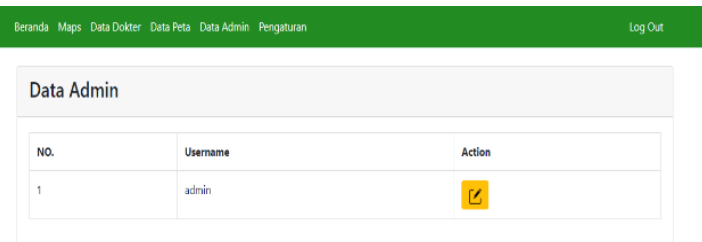

Picture 8. Admin Data Page

Based on Picture 8, it is the stage of displaying admin data. On this page there is an edit button that can be used to make changes to admin data, admin data can only be made changes, you cannot add admin data and there are several features to go to other pages.

h. Settings Page

The setting page design can be seen in Picture 9.

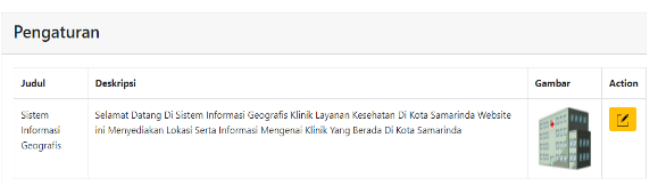

Picture 9. Settings Page

Based on Picture 9, it is the stage of displaying data on the homepage. On this page there is only an edit button that can be used to make changes to the data contained in the homepage. Data on the home page can only be edited.

i. Edit Settings Page

The setting edit page design can be seen in Picture 10 .

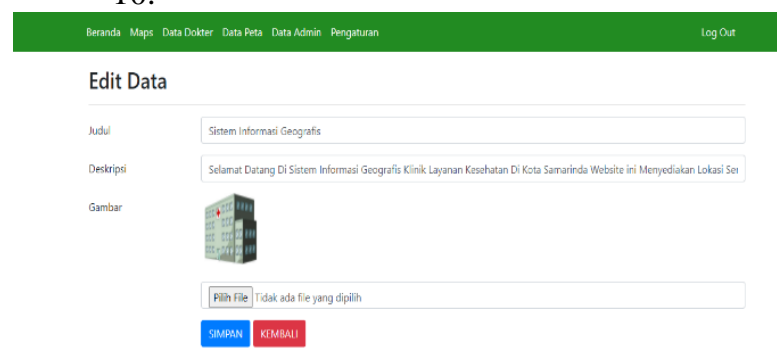

Picture 10. Edit Settings Page

Based on Picture 10 on this page, you can edit or change the existing data on the homepage which consists of title, description and image data. 
2. User Menu Display

a. Home Page

The home page design can be seen in Picture 11.

Sistem Informasi

Geografis Klinik Layanan

Kesehatan Di Kota

Samarinda

Selamat Datang Di Sistem Informasi Geografis Klinik
Layanan Keschatan Di Kola Samarinda Website ini

Menyediakan Lokasi Serta Informasi Mengenai Klinik

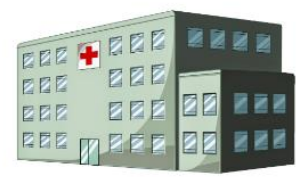

Picture 11. User Home Page

Based on Picture 11 is the web homepage display for the user, this page will display the web title, home menu, maps menu, doctor data menu and a text area in the form of a brief explanation of the web.

b. Map Page

The map page design can be seen in Picture 12 .

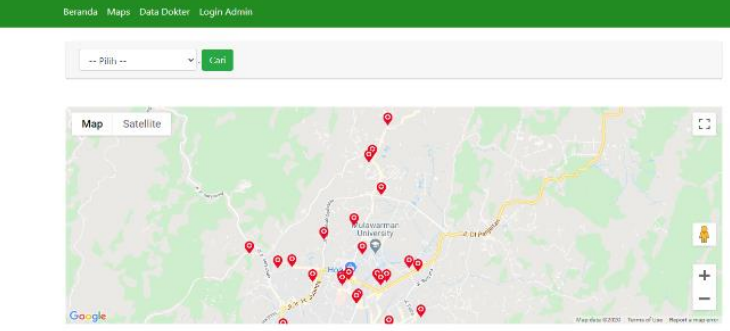

Picture 12. User Map Page

Based on Picture 12, it is the stage of displaying a map or location point of the clinic, and there is a clinic search feature, homepage, maps and doctor data.

c. Doctor Data Page

The doctor data page design can be seen in Picture 13 .

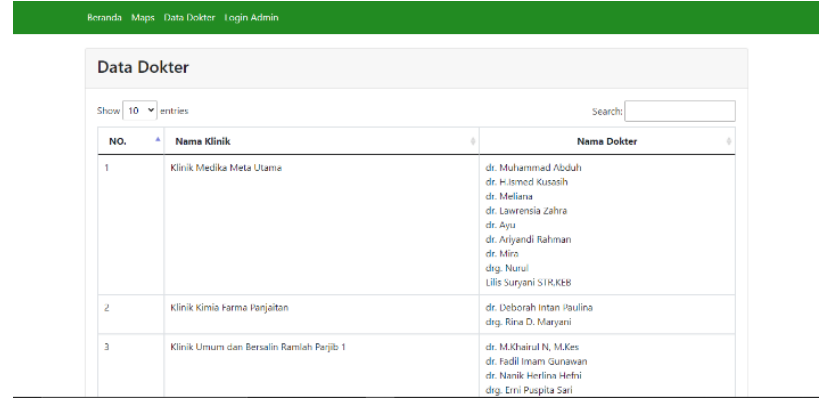

Picture 13. User Doctor Data Page

Based on Picture 13 is the stage of presenting doctor data and clinical data. On this page there is a search to perform a search based on the name of the clinic or the name of the doctor.

\section{CONCLUSION}

Based on the results and discussions that have been described previously as well as the results and analysis of the design and development of a web-based geographic information system for health service clinics, it can be concluded that this geographic information system is a tool for admins and users in the process of knowing the distribution of location points and information about the clinic. which is in Samarinda. At each location point this map has information about the clinic facilities along with pictures and there is a route location.

In the future, this geographic information system can still be developed in line with the development of user requirements specifications. This application can be developed with a more attractive appearance. This application is made based on mobile (Android) so that it can be used anywhere.

\section{REFERENCES}

Aprianti, Winda, and Witri Sari Nurfajriyah. 2016. "WebBased Geographical Information System for Health Services in Pelaihari District." Journal of Science \& Informatics 2 (2): 116-21.

Dyah P.A, Nur Rochmah, and Efawan Retza Arsandy. 2016. "Geographical Information System for Specialist Doctor Practices in the Province of D.I. Web Based Yogyakarta. " Mulawarman Informatics: Computer Science Scientific Journal 10 (1): 65. https://doi.org/10.30872/jim.v10i1.22.

Ekadanata, Andree, Sonya Dewi, Danan Prasetyo Hadi, Dudy Kurnia Nugroho, and Feri Johana. 2011. "Geographic Information System for Management of Landscapes Based on Natural Resources." PT. Mother Earth 1: 1-38.

Jamil, Zubair Shobrun, Dedy Irfan, and Titi Sriwahyuni. 2015. "Designing a Web-Based Information System for Mapping Health Facilities in Padang City Using Google Maps API" 3 (1): 1-10. http://ejournal.unp.ac.id/index.php/voteknika/article/v iew/5162.

Julianti, M Ramaddan, Agus Budiman, and Agil Patriosa. 2018. "Designing a Web-Based Geographical Information System for Mapping of Pharmacy Locations in the City of Bogor." Journal of Sisfotek Global 8 (1): 13-19.

Mardhana, Herwin, Septya Maharani, and Heliza Rahmania Hatta. 2016. "Using Dijkstra's Algorithm Method."

Priyanto, Eko, Kurnia Muludi, and Rose Irawati. 2013. "Designing a Web-Based Geographical Information System (GIS) for the Provision of Information Facilities and Personnel at the University of Lampung." Proceedings of Semirata FMIPA University of Lampung 1: 167-72. 
Ramadhani, Syaifudin, Urifatun Anis, and Siti Tazkiyatul Masruro. 2013. "Design of Geographical Information System for Health Services in Lamongan District with PHP MySQL." Technical Journal 5 (2): 479-84.

Siswanto, Joko, and Muhammad Jazman. 2016. "WEBGIS DESIGN FOR MAPPING SOCIAL PANTI LOCATIONS USING PMAPPER (Case Study: Social Service and Cemetery of Pekanbaru City)." Journal of Information Systems Engineering and Management, 2 (2), 137-143.

Swastikayana, I Wayan Eka. 2011. "Web-Based Geographical Information System for Tourism Mapping of Gianyar Regency (Case Study at the Gianyar Regency Tourism Office)." Geographical Information Systems 1 (1): 1-163. https://doi.org/10.1007/978-90-481-3609-4. 
